\title{
The role of semiotics in connecting the spaces, words and embodied experiences of refugee politics
}

\begin{abstract}
Despite the every-day prevalence of the term 'refugee', fundamental questions often remain unasked. What meanings do actors associate with the label? What intentions might be driving the word's use and/or manipulation? And what implications might the existence of multiple interpretations have for the persons under discussion and the processes within which they sit? Though this is evidently important in popular accounts, where the term's misuse fuels anti-immigration sentiments and societal mistrust, the ramifications of these multiple interpretations for assisting refugees and negotiating durable solutions have lacked critical exploration. Existing approaches to understanding the politics of the refugee regime have tended to focus on physical sites of contestation, such as refugee camps. This article re-introduces semiotics as a heuristic framework through which to understand how the word 'refugee' in itself constitutes a disputed arena, and to explore what impacts this has on negotiations over their future. This approach is used to explain the controversial negotiations surrounding the invocation of the Cessation Clause for Rwandan refugees in Uganda. Extensive resistance to the cancellation of Rwandan refugees' statuses has not been met by commensurate attempts to explain when, why and how this process unfolded. Through conceptualising the word "refugee" as a sign according to the Saussurean and Barthean models of semiotics, this piece charts the multiple meanings that this label signified alongside its established legal-normative definition, and discusses what implications this had for how durable solutions were negotiated. Disaggregating the label provides a route through which to explore what enables the conceptual and spatial dissonance that plagues certain attempts to conclude protracted refugee situations. The piece concludes by discussing the analytical possibilities that emerge from re-engaging with socio-semiotic approaches, including through proposing greater engagement with the political geographies of words and their meanings.
\end{abstract}

\section{Keywords}

Refugees; semiotics; Rwanda; Uganda; Cessation Clause 


\section{Introduction}

The word refugee is irreducibly polyvalent. It is simultaneously embodied by individuals, used to refer to a legal status and responsibilities, and signifies a host of broader social, political and societal issues. Understanding responses to refugees requires exploring the multiple meanings invested in this linguistic 'space', and the relationships that exist between these and activities to support displaced individuals on the ground. Non-legalistic approaches to spaces of 'refugeehood' have tended to analyse material sites of political contestation, including refugee camps (Khalili 2005; Lischer 2006; Peteet 2005a) and the bodies of refugees. This is often approached through Agamben's (1998) theory of homo sacer (Diken 2004; Isin 2009), despite its ongoing contestation (Ramadan 2012; Owens 2009). Negotiations over refugees' futures have generally been analysed around key themes: sovereignty and borders (Haddad 2008; Gibney 2004); security (Ceyhan et al 2002; Huysman 2000); and state interests and international relations (Betts et al 2010; Loescher 1992). These perspectives each illuminate crucial parts of the story, but leave questions concerning how actors intentionally reinforce, understand and utilise the connotative potential of words during these negotiations, and the significance of this behaviour for how and why 'progress' is achieved, somewhat underexplored. As Couper $(2007,281)$ states, 'one of the more specific, and perhaps most obvious, problems associated with the context-dependent meaning of words is that the same word may be used to mean different things, leading to misinterpretation among individuals who think they understand each other.'

Recognising that the word refugee is fraught with competing interpretations is of course not new (Hilhorst et al 2012; Zetter 1991; 2007; Malkki 1996). Refugees have been widely documented as alternately appropriating, transforming and rejecting their label as a tool of differentiation (Arendt 1943; McConnell 2013; Kumsa 2006). At points when actors are deciding whether or not the label should be withdrawn from individuals, academic approaches have focused on legal analyses of words and frameworks (Fitzpatrick 1998; Tarwater 2000; McMillan 2012). Limited attention has been given, however, to empirically grounded assessments of how non-refugee actors have come to understand the label beyond its initial legal definition. Shacknove $(1985,276)$ nonetheless cautioned early on within Refugee Studies that the failure to respond adequately to refugees is 'only partially attributable to 
political conflicts and resource scarcity, for conceptual confusion...contributes to the misery of both refugee and host and to the inflammation of international tensions.'

Though rooted in questions concerning how language is structured and used, studies exploring this 'conceptual confusion' in practice have mostly sidestepped linguistic theory. Zetter, for example, argues that the word 'refugee' has multiple definitions, with 'fluctuating values and exchange rates' that continually act 'to destabilise the solidity of the legal category' $(1991,40)$. This makes the label amenable to supporting the differing interests of states, bureaucratic entities and refugees alike (Malkki 1992; 1996; Zetter 2007). Though these pieces present important commentaries on the performative and pliable features of the word refugee, they skip over a critical distinction. They fluctuate between the fragmentation of the 'refugee' category in to new labels - asylum seeker, illegal immigrant, economic migrant - and the proliferation of new meanings ascribed to the existing word.

These two processes constitute different endeavours, politically and conceptually. A paradigmatic change produces new vocabularies, allowing states to avoid fulfilling their responsibilities under the 1951 Convention Relating to the Status of Refugees (herein the 1951 Convention). In contrast, the continued use of the refugee label legitimises the United Nations High Commissioner for Refugees (UNHCR) involvement in the sovereign affairs of states, provides states with access to the political and financial resources of the refugee regime, and establishes an international framework through which a minimum threshold of rights and responsibilities - not least non-refoulement - are technically upheld. For various actors, ascribing refugee status to populations while attempting to disassociate it from particular connotations may therefore prove a more profitable approach than disregarding the label altogether. Herein lay the central paradox from my fieldwork: though all those I spoke with were discussing Rwandan refugees, it was not clear when, or indeed if, these words were being used to refer back to either displaced individuals or legal entitlement. Making sense of this latter process requires a theoretical framework to explain how certain spaces, including words and labels, can see their meanings transformed over time, and with what potential effects.

In this paper, I propose semiotics for this task by applying this framework to the contentious case surrounding the future of Rwandan refugees in Uganda. In 2009, UNHCR recommended the application 
of the 'ceased circumstances' Cessation Clause to Rwandan refugees. This Clause - Article 1C(5) of the 1951 Convention - allows UNHCR and states, rather than the refugees themselves, to declare that 'the circumstances in connexion with which he has been recognised as a refugee have ceased to exist' and therefore 'he can no longer...continue to refuse to avail himself of the protection of the country of his nationality' (UN General Assembly 1951). As refugee status is based on individuals fulfilling two reversible conditions, this pathway to losing the label is implicit from its initial designation. This requires that the affected persons are displaced from their Country of Origin $(\mathrm{CoO})$ and that their situation satisfies the legal nexus contained in Article 1A(2) of the 1951 Convention or other related legal documents.

UNHCR's recommendation for the Clause's application to Rwandan refugees was met with consternation, and has remained hugely controversial since. Literature analysing this announcement has been heavily polarised, with arguments condemning its invocation (for example, Hovil 2010; Fahamu 2011) clashing with UNHCR's defence of its position (for example, UNHCR 2009; 2010b). Neither approach has explained the ten years of debate that has occurred since the Clause's application first came under discussion, nor the gap that has emerged between stakeholders agreeing to invoke Cessation and the establishment of practical plans to make this happen. It will be argued that as how we 'read' objects and spaces shapes how we respond to them, charting the evolving and competing interpretations of what 'Rwandan refugees' meant to those engaging with them is central for understanding how and why these negotiations 'progressed' as they did (Hardy and Phillips 1999).

Based on fieldwork tracing the reception and implementation of the Cessation Clause in Rwanda, Uganda and Geneva, and discussions with Rwandan refugees and advocacy organisations across the region and farther afield, this piece seeks to do two things. First, through explaining the disjuncture that emerged between the Rwandan refugees on the ground and the objects of the multi-lateral negotiations over Cessation, the article illustrates the explanatory potential of semiotic studies in to the political geographies of words and their interpretations. This highlights the interconnections of text, discourse and embodied experiences, and how we might understand the conceptual and geographical relationships between them. Empirically, methodologically and theoretically, this challenges the concern that the 
'esotericism' of semiotic geography results in it lacking a principled connection to the world outside of the text (Jackson 2000; Philo 2000). The paper's core aim therefore is to promote geography's reengagement with politically and socially situated semiotic approaches (Jensen 1995) by highlighting their value in exposing and explaining diverse, disputed arenas in geographical enquiry, not least the refugee label itself.

\section{Semiotics and geography}

Semiotic approaches are theoretically diverse but linked by their rejection of the notion that 'things' coincide with inherent and immutable meanings. Their central object of study is the sign, defined as 'everything which can be taken as significantly substituting for something else' (Eco 1976, 7). Semiotics presupposes that when individuals interact with an entity, they will associate it with related ideas, emotions and objects due to their largely unconscious socialisation in to certain cognitive patterns, or due to intentional attempts to shape meaning. Though the meanings of language and signs are therefore understood as ontologically arbitrary, systems of convention exist that provide the shared platform essential for communication. The theoretical emphasis of semiotics lies in explaining the dynamic interpretation of these signs - be they places, objects or words - and the systems of conventions, across time and space.

The adoption and popularity of semiotic theories within geography peaked in the 1980s, with geographers applying these traditionally linguistic approaches to landscapes to highlight that 'places have power' and can be read as texts that communicate meanings to, and acquire meanings through, the entities that traverse them (Boogaart 2001, 39; Duncan et al 1988; Lagopoulos 1993). Though defining a short-lived era of cultural geography, extensive critique resulted in these approaches largely disappearing from the discipline's theoretical repertoire in the 1990s. The turns to non-representational, performative and material geographies reflected the rejection of semiotics for its lack of attention to affective experiences, its inability to 'articulate well diverse ways of seeing and knowing' (Flowerdew and Martin 2005, 262), and its often inaccessible and structurally determinist exploration of meaning and its creation (Vannini 2007). Others objected to its reification of a binary between texts and their 
audiences, its masculinist positioning of academics as privileged and transcendental 'readers' of the relationship between these two components (Rose 1993; Hoggart et al 2001) and its inattentiveness to the material, rather than purely cultural, production of space (Curt 1994). Cultural geography's fixation on the 'world as text' was 'charged with collapsing meaningful social life into arbitrarily fixed, closed structures of signification' (Revill 2011,375), with the possibility of agency and alternative readings largely lost.

Re-modelled applications of semiotic theories and methodologies, however, illustrate their continuing analytical value in geographical scholarship (Blommaert 2010; Scollon and Scollon 2003; Hinchcliffe 2003). While phenomenological and affective accounts of place explain the impressions and attachments of those inhabiting it at a given moment, proponents of semiotics argue that they risk missing certain qualities, constraints and thereby structures upon which interpretations rest (Shortell 2016). Those re-adopting this socially-situated semiotics nonetheless eschew traditional structuralist ontologies. They argue that capturing meanings depends on studying lived uses and practices in their iterative, multiplicitous relationships with the structures, ideas and objects that simultaneously inhabit space (Vannini 2009; Mol 2003; Van Leeuwen 2005). Responding to criticisms that studies framed by semiotics are 'loosely impressionistic and highly unsystematic' (Chandler 2007, 221), they present as much as possible the spectrum of interpretations that surround a text, object or space in their wider social, cultural, geographical and historical milieu. Importantly, objects of inquiry include non-human objects and their social worlds, with biosemiotics and the material semiotics of actor-network theory informing much geographical scholarship in to the ways that meaning is contested and stabilised through these objects and actions (Von Uexküll 1982).

As a way of looking at the world, therefore, socially-grounded semiotics is argued to offer 'ideas for formulating questions and ways of searching for answers' (Van Leeuwen 2005, 1) in, for Hinchcliffe (2003), an experimental and creative way that maintains a focus on materiality while exposing active associations, contingencies and alignments between all that composes space. While remaining uncomfortable with the ontological and temporal 'snapshots' that their analyses rely upon, these are seen as a socially responsible and theoretically necessary alternative to deconstructing ad infinitum. 
Within critical geography, semiotic theories continue to be most commonly referenced when analysing landscapes as spaces of contested meanings (Barnes et al 2013; Lindström et al 2012; Metro-Roland 2011). Studies range from those exploring the intersubjective, spatialized experiences of urban transformation (Vasudevan 2003; Lees 2002; Sanyal 2014) through to those documenting the refugee camp as a disputed zone of past and aspirational identities, and competing political agendas (Ramadan 2012; Peteet 2005a). Beyond physical spaces, these theoretical approaches have been applied to conceptual apparatus such as the 'state' (Painter 2006), physical objects such as the elephant (Barua 2013) and the ordering of geographical disciplinary boundaries (Couper 2007). With particular relevance to this piece, they have also been applied to interpret words such as 'home' and 'repatriation' during processes of refugee return (Black 2002; Peteet 2005b).

The majority of this work, however, only alludes to semiotics, and research applying these linguistic models to the political geographies of words - including 'the nature, making, transmission and understanding of meanings' within and through them (Revill 2011,378) - remains uncommon. Of this work, Couper, Painter and Metro-Roland provide the only accounts of how linguistic theory per se can enhance our understanding of real world phenomena, using the work of Wittgenstein, Bakhtin and Peirce respectively. Rarely is semiotics employed as a structuring device for observations vis-à-vis the multiple and relational orders of meaning associated with the same spaces, objects and texts, not least because of its historical dismissal as reductive, subjective and often simply 'old-fashioned'. Its heuristic potential for highlighting the transformation that meanings undertake as they move from 'being energies, matters, object, into thoughts, ideas, cultural artefacts and vice versa' (Revill 2011, 380) is thus also lost. Both qualities are important for this analysis. The word 'refugee' circulates meanings between physical, discursive and affective registers; between the bodies of the displaced, the words of legal documents, and broader cultural, normative and political contexts. Tracing these is the first challenge; relating them to each other, empirically and theoretically, the second.

\section{The theoretical framework}

This work draws upon the early work of Barthes and Saussure (Duncan et al 1988). Much like those geographers who argue that language and discourse do not exist in a secondary, referential relationship 
to any a priori, metaphysical, material world (Kearnes 2003), Saussure (1983) wished to show the varied and vital role played by language in forming and shaping our environs. He broke the linguistic sign in to two, aggregate elements: the signifier, composed of the abstract acoustic image formed in our minds during speech, and the signified, composed of a concept with which the signifier maintains a contingent association. He wished to illustrate that 'words do not exist as the dictionary portrays them....as fossilised exhibits like dead butterflies in the entomologist's glass case' (ibid., xxxvii). The signifier and signified can change, and the same sign can be simultaneously associated with numerous interpretations (Barthes 1972). As Barthes described in Mythologies (ibid.), actors and societies may appropriate signs, attempt to empty them of any discordant meanings, and then fill them with their own - often partisan and highly exclusionary - systems of signification. It is here that the scope for 'misinterpretation' discussed by Couper (2007) becomes apparent.

Barthes expanded Saussure's work to explore the simultaneous tiers or orders of meaning contained within a sign, as illustrated in figure 1 . The first-order of signification was shown to be comprised of the signifier and the signified, which combined to produce a sign. This sign was then said to transform in to a signifier, shifting it from conveying meaning to constituting a form alone. Once joined with a new signified, this created the second-order sign. Barthes' christened this concept at the second-order, which he considered constituted myth, the 'signification'.

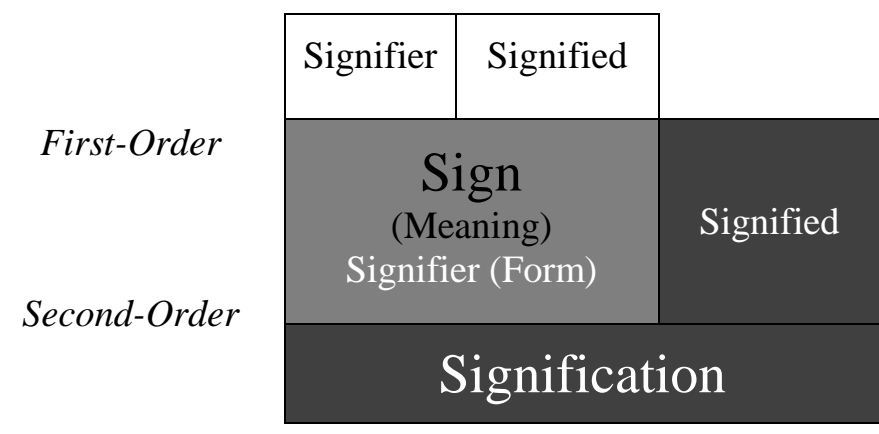

Figure 1. The multiple orders of the sign. Adapted from Barthes (1972).

This multi-tiered system was not intended to hide the first-order system of meaning. Barthes (1972, 117) stated that, 
'The meaning will be for the form like an instantaneous reserve of history...the form must constantly be able to be rooted again in the meaning and to get there what nature it needs for its nutriment; above all, it must be able to hide there. It is this constant game of hide-and-seek between the meaning and the form which defines myth.'

Between the two orders, there is neither an absolute break in content nor in form as they exist in an interdependent, evolving relationship. Patterns of cognitive association change and new signifieds proliferate in line with political processes and socio-historical conditions. These changes affect the behaviour of those interacting with the sign, which, in turn, influences back upon its constituent parts. Barthes $(1972,119)$ thus contended that myths surrounding language, objects and spaces are always fundamentally transient because signs at both orders can never be finitely restricted.

Though the current complexity of semiotic models used in landscape and media studies far exceeds that outlined here, this article highlights two key ways in which conceptualising the word refugee through this two-tiered framework helps explain the practical and spatial disjuncture seen in the following case study. First, it draws attention to the changing signifieds that different actors have associated with Rwandan refugees and the Cessation Clause more generally. Second, it explains how these interacted with other meanings to enable a particular kind of consensus to be reached around the Clause's eventual invocation. This emerged from the codification of a specious discursive and spatial separation between the two orders of meaning; between the abstract 'Rwandan refugees' at the centre of negotiations and the individuals whose displacement and legal status first brought this sign in to being. As Eco $(1976,7)$ states, while signs are characterised by the fact that they conjure other meanings at the point of reception, 'this something else does not necessarily have to exist or to actually be somewhere at the moment in which a sign stands for it.' Addressing the first-order signified and signifier of these refugees - corresponding to individual's fulfilment of the refugee definition and living in exile, respectively has thus been increasingly neglected even as discussions about 'Rwandan refugees' have intensified and nominally progressed. A framework drawn from semiotic theories is subsequently employed to explain how and why such an outcome occurs beyond bureaucratic, administrative and capacity failures, 
and with what possible effects. First, however, the status of Article $1 \mathrm{C}(5)$ within Uganda will be contextualised.

\section{The Cessation Clause for Rwandan Refugees}

At the turn of the Millennium, following decades of ethnically-driven displacement from Rwanda, including the Genocide that caused over a million to flee, at least 55,000 Rwandans were registered as refugees (UNHCR 2010a). These included those whose de facto integration in Countries of Asylum (CoAs) meant that they saw 'return' to Rwanda as an anachronism (see Ho 2012 for a comparison), and those who feared for their safety upon return because of accusations levelled against them for participating in the Genocide (Hovil 2010). The Noughties nonetheless marked the advent of UNHCR's discussions, which stretched to its field offices and governments hosting Rwandan refugees, vis-à-vis the applicability of the Cessation Clause to this caseload.

The 'first order' of events: the search for tangible solutions for Rwandans in exile

Much to the disapprobation of the Government of Rwanda (GoR), it was not until 2009 that the UN High Commissioner for Refugees confirmed that UNHCR would 'positively respond to the insistent request of the Government of Rwanda to invoke the Cessation Clause' because, 'given the level of peace, stability and development in the past 15 years and the political will to encourage repatriation, there is no longer any justifiable reason for Rwandans to remain in a refugee status abroad. ${ }^{1}$ CoAs were instructed to establish durable solutions for all Rwandan refugees by the $31^{\text {st }}$ December 2011 , when the organisation recommended that Article $1 \mathrm{C}(5)$ be invoked to cease their statuses.

Throughout these initial negotiations, the Rwandan Government and UNHCR sought to address this caseload as a legal problem and presented 'objective' reasons, couched in legal-technocratic language, for withdrawing their status. UNHCR formulaically reasoned that "the main thing taken into account is whether the situation that forced people to flee still exists.... for Rwandans, obviously the genocide and the war is over" (quoted in UK Immigrant Magazine 2011). This suited the GoR, whose posturing in

\footnotetext{
1 'Joint Communique on the Occasion of the Visit of Antonio Guterres', 19 October 2009. Unpublished. Author's own.
} 
the post-Genocide era - including intrusions in to the Democratic Republic of the Congo and forced repatriations of Rwandan refugees from Uganda in 2007 and 2010 (UNHCR 2010c; Human Rights Watch 2010) - suggested that the return of its refugees was a primary goal. They were concerned about rising political dissent (Nyamwasa et al 2010) and mobilisation within those in exile. ${ }^{2}$ Cessation would have refuted the presumption that these individuals were leaving Rwanda en masse for Convention reasons. Cessation therefore provided the GoR with an avenue, supported by 'a stamp of approval from the UNHCR' (Rwandan Minister of Foreign Affairs, cited in Kagire 2012), to nullify the signified and signifier for all Rwandan refugees. The GoR hoped that Governments in CoAs would similarly interpret this caseload at the first-order of signification - as displaced bodies with legal entitlements - and follow their prescriptions for the repatriation of Rwandan refugees accordingly.

Other parties to the negotiations did not wholly support this depoliticising and dehistoricising strategy. As one UNHCR employee stated, the organisation's decision to invoke Cessation had been made on a "fifty plus one" basis and views remained divided. ${ }^{3}$ Beyond immense concerns about the practicalities of invoking the Cessation Clause, Government of Uganda (GoU) representatives' questioned its prematurity given ongoing government-orchestrated human rights abuses within Rwanda. They felt that it wrongly endorsed the country's political trajectory as there was little evidence to suggest that either component of the refugee label could have been responsibly reversed. ${ }^{4}$ Though much of the GoR's dismissiveness towards these refugees occurred in private, ${ }^{5}$ moments of public denunciation (Kabeera 2011; Kagire 2012; President Kagame 2011) exacerbated these actors' reservations about the Clause's suitability. Furthermore, Rwandans in exile and parties supporting their cause advocated that

\footnotetext{
${ }^{2}$ Interview with journalist from The Monitor, Kampala. December 2012.

${ }^{3}$ Interview with staff member from UNHCR, Geneva. September 2014.

${ }^{4}$ Interviews with Minister in GoU, and employees of the Office of the Prime Minister, Kampala. October to December 2013.

${ }^{5}$ An Internal Briefing Document prepared for the Rwandan Delegation on points to discuss in a bilateral meeting with the Government of the DRC in the late 2000s illustrates the GoR's attitude at the time towards their refugees:
}

'The Rwandese refugees still living in DRC are there by choice...because of their attachment to the genocidal ideology of FDLR or because of some other material gains. They should be treated as such (criminals freeing [sic] justice, unrepentant genocidal suspects or economic migrants) and not as refugees because there is nothing (no persecution) that prevents them from coming back.' 
international protection for this caseload must continue (Fahamu 2011; 2012). Reconciling these groups' contradictory views on Rwandan refugees to form an agreement that included tangible durable solutions, especially voluntary repatriation, was thus a fruitless task.

UNHCR succumbed to this opposition in 2011. Their amendments to the Cessation Clause included pushing its invocation back to $30^{\text {th }}$ June 2013 , and limiting its recommended application to refugees who had left the country in response to events that had occurred between 1959 and the end of 1998 (UNHCR 2011, para.4). Refugees who fled from 1999 onwards were declared exempt from the Clause's effects.

The 'second order' of events: empty agreements around abstract 'refugees'

The amended dates illustrated UNHCR's awareness that securing support for Cessation would be difficult if high-level dialogues were linked too prescriptively with quantifiable outcomes for actual refugees. As the following section will show, the evolving political and symbolic significance of 'Rwandan refugees' to each of these actors did nonetheless encourage their rhetorical commitment towards the Clause's eventual invocation. The three main parties thus became set on ending politically harmful negotiations on this topic, even if the practical pathways for assisting Rwandan refugees remained blocked. Even so, the GoR did not welcome the Clause's new temporal limitations. They foreclosed the possibility of all its citizens repatriating, and implied a widespread recognition that conditions within Rwanda were still causing individuals to flee. Rwandan refugees and the Cessation Clause thus came to connote - naturally and through intent - a number of new signifieds to the regime in Kigali.

Refugees have long signified a state's failure to guarantee the legal and human rights of its nationals (Haddad 2003). In the Rwandan case, Hovil $(2010,19)$ argues that they 'must be read as an indicator of the [country's] general ill health in governance' and 'an ongoing reminder of the ethnic tensions that are supposed to have been addressed' (ibid., 1). Extensive discussions about the Clause's applicability challenged the GoR's sanctioned account of the country's history of ethnic violence, and the Rwandan 
Patriotic Front (RPF) saw them as 'tarnish[ing] the good reputation of [their] country. ${ }^{6}$ The refugee figure also came to signify the State's decreasing ability to command decision-making in international fora. One Ugandan Minister emphasised that the RPF's fixation on achieving consensus after the Clause's 2011 amendments was largely intended to illustrate their continuing ability to broker deals to their advantage.

With this caseload of refugees signifying two major embarrassments to the GoR, Rwandan authorities appeared to subtly change track in how they sought to achieve cooperation with CoAs and UNHCR over these refugees' futures. One way was through partially re-defining the word 'refugee', by alternating between the word's original signified and signifier and the GoR's own, more complimentary 'readings' of this group. As Barthes $(1972,121)$ states, 'the signification of the myth is constituted by a sort of constantly moving turnstile' whereby there is value for actors in the seamless alternation between the first- and second-order of meaning. On the one hand, discussing those individuals as refugees has enabled the GoR to maintain a dialogue with UNHCR and the GoU about responsibilities towards this group and the applicability of Cessation. On the other hand, the Rwandan authorities have sought to re-define 'Rwandan refugees' so that they do not reflect badly on contemporary governance. While the GoR presents refugees affected by Cessation as the result of state-orchestrated violence by the country's previous government, the "one or two or three refugees outside Rwanda who fled after 1998" are discussed as having fled due to personal deficiencies - such as being "hard core criminals" 7 - rather than any systemic problems with the Rwandan state. ${ }^{8}$ Interviews suggested that neither UNHCR nor CoAs bought in to this distinction. The RPF's ability to reframe why individuals fled the country after 1998 has nonetheless enabled these parties to continue using the word 'refugee' in reference to this group without offending the Rwandan regime.

\footnotetext{
6 'Proceedings of the Fourth Meeting of the Tripartite Commission Meeting for the voluntary repatriation of Rwandan refugees in Malawi.' Held in Kigali on $19^{\text {th }}$ October 2007. Unpublished. Contained in MIDIMAR Archives. Author's own.

${ }^{7}$ Interview with Rwandan Ambassador to Uganda, Kampala. November 2013.

${ }^{8}$ Interviews with MIDIMAR, the Ministry of Local Government, the Ministry of Foreign Affairs and Cooperation, and the Rwanda Governance Board, Rwanda. November and December 2013.
} 
A second GoR mechanism to encourage consensus has been through pushing for agreement over the Clause's future invocation without demanding evidence of how this would translate in to practical responses to refugees. Senior representatives of the Rwandan Ministry of Disaster Management and Refugee Affairs (MIDIMAR) confirmed that they had strategically shifted from being fixated on return, as resistance to this had prolonged unflattering discussions about domestic politics, to seeking ways to facilitate the end of refugee status - or at least discussions about it - "in any way possible." MIDIMAR (2013) heralded their new scheme to provide passports to refugees requesting local integration in CoAs because it would 'reduce the number of refugees re-applying for [protection] and forging false reasons tarnishing the image of our country. ${ }^{10}$ Ugandans employed in the refugee industry recognised this as an attempt to "soften the appearance" of Cessation, ${ }^{11}$ and to expedite agreement over the Clause's suitability by ameliorating CoA's reasons for opposing it.

Multiple interviewees therefore felt that these negotiations had descended into a "game" for the GoR. The 'major victory' (Kagire 2013) had been in acquiring support for the cancellation of refugees' statuses 'as a proxy validation of the country's peace and stability' (Cole 2015, 18), not for the practical implementation of durable solutions. One prominent human rights organisation attributed its disengagement from lobbying against the Clause to its assessment that the negotiations had become a conjectural "definitional fight" over the refugee label that were unlikely to lead to any serious changes, for better or worse, for "actual" Rwandan refugees. ${ }^{12}$ Several interviews supported this. The following quote from UNHCR's main non-governmental Implementing Partner in Uganda shows the prevalent sense that commitments to durable solutions made in high-level dialogues would remain rhetorical:

"What governments will really take serious decisions on Rwandan refugees? ...UNHCR should have made governments take concrete steps on what would happen to refugees from the start, rather than just try to get Cessation on paper as the lack of pressure on

\footnotetext{
${ }^{9}$ Interviews with MIDIMAR senior staff members, Kigali. November 2013.

${ }^{10}$ MIDIMAR (2013) 'Strategies for Implementation of the Cessation Clause for Rwandan Refugees', Kigali, May 2013. Unpublished. Author's own.

${ }^{11}$ Interview with staff member at OPM, Kampala. October 2013.

${ }^{12}$ Interview with staff member, Kigali. November 2013.
} 
governments has meant that they have never thought hard about how to provide durable solutions"13

The GoU and UNHCR appeared to tacitly champion this shift. With their pre-2011 reservations about the Clause's application ameliorated, the significance and meanings that they have associated with these groups beyond their legal-normative status have incentivised these actors to voice public support, albeit rhetorical, for the Clause's eventual invocation. For UNHCR, this group signifies the organisation's inability to establish durable solutions, given some of whom have resided in Uganda for half a century. They also provide a continuing reminder of UNHCR's failures vis-à-vis Rwandan refugees during the 1994 Genocide and its aftermath (Howland 1998; Mills et al 2002). Staff at the organisation admitted that "nobody has huge hopes" of Cessation inducing mass repatriation, ${ }^{14}$ in part because "this caseload is protracted for the precise reason that these are the ones who do not want to return." ${ }^{15}$ Given their highly contentious significance, the organisation has nonetheless celebrated the attainment of even a rhetorical consensus between stakeholders over these refugees' futures.

For the GoU, Rwandan refugees have acquired multiple signifieds over generations in Uganda. Interviewees spoke of them constituting a critical physical resource, as exemplified when fighting with President Museveni's National Resistance Army (McDonough 2008), and a useful set of aces for maintaining political leverage in negotiations with Uganda's neighbours. ${ }^{16}$ Recently, however, Rwandan refugees have signified the unresolved domestic debate concerning refugees' right to naturalise within Uganda, and the sensitive bilateral relations surrounding the GoU's continuing recognition of state-orchestrated persecution within Rwanda (Cole 2015). One Ugandan Minister disclosed that the GoU had therefore conceded of late to appear openly supportive of the Clause because they “don’t want to anger Kagame.” Further informed by Rwandan refugees' obvious resistance to return, they have nonetheless pursued a de facto policy of "punching holes in the Cessation Clause". ${ }^{17}$

\footnotetext{
${ }^{13}$ Interview with staff member, Kampala. December 2013.

${ }^{14}$ Interviews with UNHCR staff members, Kigali and Geneva. Throughout 2012 and 2013.

${ }^{15}$ Interview with staff member at UNHCR, Kigali. November 2013.

${ }^{16}$ Interview with staff member at the Office of the Prime Minister, Kampala. December 2013.

${ }^{17}$ Interview with Minister in the GoU, Kampala. November 2013.
} 
The GoU has chosen to make a placatory, ceremonial commitment to Cessation in the hope of halting further bilateral and domestic negotiations over a label so manifestly tainted by controversy.

\section{Divergent connections between the first-order and second-order 'Refugee'}

As one refugee rights activist stated, "Kagame and Museveni have their own interests behind all of these refugee affairs, and none of them are genuinely in line with the Convention."18 'Rwandan refugees' in Uganda progressively came to signify a worsening political indictment of the Rwandan state, a political liability to the GoU, and the ongoing impotence of UNHCR to secure this population durable solutions. The three main parties' recent behaviour during negotiations over Rwandan refugees nonetheless suggests that it was the desire to mitigate these political and symbolic connotations, associated with this caseload at the second-order of signification, that served to incentivise cooperation where legal responsibilities and the lived experiences of protracted exile had previously failed to. The result, as will be discussed in greater detail below, has been that agreements over Rwandan refugees have been emptied of action, and become geographically and conceptually detached from the affected individuals on the ground. Hinting at this, one MIDIMAR technocrat lamented that "we'll die before the Cessation Clause is implemented and it will only be words." 19

I attribute this shift not to bureaucratic ineptitude or a temporal lag, but to these actors exploiting the perceived distance between 'Rwandan refugees' at the second-order of signification and Rwandan refugees as individuals entitled to tangible support and protective mechanisms. Semiotic approaches have long theorised the potential of this phenomenon to occur. As Eco (1976) states, 'signs can be used to lie, for they send back to objects or states of the world only vicariously.' In a trend commonly associated with the era of post-modernism and hyper-circulation, signs can become entirely disconnected from their original concept and form (Baudrillard 1981). If words then acquire a value independent of the material forms they may have originally described, they may themselves enter a political economy as important units of exchange (Irvine 1989). This appears to have occurred in this

\footnotetext{
${ }^{18}$ Interview in Kampala. October 2013.

${ }^{19}$ Interview with senior staff members at MIDIMAR, Kigali. November 2013.
} 
case: negotiations about 'Rwandan refugees' came to serve valuable political ends for the main actors involved precisely because they had no intent to link these with the embodied signifieds or legal signifier of this label.

As Barthes' framework shows, however, the levels of meaning in words such as 'refugee' are inextricably connected. The multi-lateral negotiations outlined above would not have occurred had the GoR dismissed these individuals as 'economic migrants' or 'criminals freeing [sic] justice', ${ }^{20}$ or if legally-recognised refugees were not present on Uganda's territory throughout these discussions. Understanding the label 'refugee' as simultaneously materially embodied, legally prescribed, and associated with broader social, economic and political significances, is thus incomplete without theorising the relational nature of these orders of meaning. In his article assessing the rise of style over substance in American foreign policy, Rogin $(1990,116)$ argues that 'substituting symbols for substance' is not an immaterial shift. The symbolic calls for arms and declarations of solidarity by American politicians, even if only intended for consumption in international boardrooms or citizens' front-rooms, 'have all too much substance for the victims of those symbols, the participant-observers on the ground in the Third World' (ibid.). Once put forth, words may be interpreted in any number of ways, irrespective of what meanings authors may have wished them to convey (Eco 1984), and this interpretive act constitutes 'a political practice which has material consequences' (Duncan et al 1988, 125).

States and UNHCR have seemed poorly seized of this fact. One senior UNHCR employee in Kigali questioned whether it mattered what information circulated about Rwandan refugees in the public arena provided UNHCR was pulling the necessary brakes on Cessation behind the scenes. ${ }^{21}$ This evidences these actors' dangerous presumption that they can control what meanings are interpreted from their discussions, namely that agreements about Rwandan refugees, which of late may have been designed

\footnotetext{
${ }^{20}$ An Internal Briefing Document prepared on points to discuss in a bilateral meeting between a Rwandan Delegation and the Government of the DRC in the late 2000s. Unpublished. Author's own.

${ }^{21}$ Interview with UNHCR staff member, Kigali. November 2013.
} 
precisely to avoid having to take steps to institutionalise durable solutions, will not be interpreted by others - such as Rwandan refugees - in ways that result in material outcomes.

On the contrary, their attempts to distance the realm of symbolic politics, shaped by second-order signifieds, from the individuals ostensibly under discussion has failed, with deleterious impacts for refugee protection. Confusion over how to interpret and respond to these refugees has translated in to uncertainty within organisations about whether to proceed with the Clause's implementation in practice, or merely to promote the party line in principle. An organisation responsible for providing University scholarships to refugees in Uganda was unsure, for example, whether it would be reprimanded for enrolling Rwandans in light of Cessation. ${ }^{22}$ More seriously, positive outcomes for Rwandans undergoing status determination in Uganda have appeared to reduce in the face of the GoR's sustained repudiation of their involvement in causing individuals to flee, ${ }^{23}$ in a pattern unfortunately predicted by some UNHCR staff. ${ }^{24}$ The human rights organisation discussed above was wrong to predict that the GoR's 'definitional fight' to re-signify how this caseload has been understood would occur without numerous detrimental effects.

The result, unsurprisingly, has been immense uncertainty within the Rwandan refugee community. Refugees have expressed confusion over what Cessation is supposed to achieve or illustrate: "if things change in Rwanda, there will [be] no need of [a] cessation clause...We shall be willing to go to our country without their help" (quoted in IRIN 2012). In response to the ambiguity surrounding who Article $1 \mathrm{C}(5)$ would apply to, the perceived reduction in recognition rates for Rwandan asylum-seekers, and the perception that repatriation is the only durable solution available, some within this group have undertaken worrying patterns of migration (Hovil 2010). Having pre-emptively left the camps in SouthWest Uganda, many have either de facto integrated in rural areas or moved to Kampala. ${ }^{25}$ The city nonetheless lacks a clear protection framework for urban refugees, which has heightened their

\footnotetext{
${ }^{22}$ Interview with staff at an education-focused NGO, Kampala. October 2013.

${ }^{23}$ UNHCR's figures suggested a $2 \%$ success rate for Rwandans' asylum applications to the Ugandan Government in 2010 (Human Rights Watch, 2010).

${ }^{24}$ Interview with UNHCR staff member, Geneva. April 2012.

${ }^{25}$ Focus Groups and interviews with Rwandan Refugees, Kampala. October 2013.
} 
susceptibility to Rwandan government agents tasked with silencing opposition (for example, see Miwambo 2014).

Signs stand in a 'reflexive relationship to other semiotic structures that participants are using...to make up their lifeworld' (Goodwin 2000, 174). It is therefore no wonder in a context of shifting information, scaremongering (Kouyate 2010; Kabeera 2011) and supposed attacks on Rwandan refugees that this group has interpreted any announcement concerning the progress of Cessation through the most paranoid of lenses. The subtleties of empty tripartite agreements over hypothetical 'refugees' have been lost to these individuals, who have responded as if discussions over 'Rwandan refugees' in distant boardrooms have referred directly to them. Actors' different understandings of the significance of this caseload may have been reconciled through the creation of an abstract scenario, of empty promises and speculative outcomes, but the disjuncture that States and UNHCR envisaged between this space and refugees' embodied experiences was a fallacy. As one individual working for an NGO in Uganda stated, Rwandan refugees now "do badly really, whatever happens." ${ }^{26}$ Several refugees indeed felt that it "doesn't really matter if the Cessation Clause actually applies to them or not," as all the rhetoric surrounding the process had undermined their protection regardless. ${ }^{27}$

\section{Discussion}

Drawing upon the heuristic frameworks of Barthes and Saussure, I have sought to contribute an explanation for protracted negotiations over Rwandan refugees by examining the multiple meanings attached to this group, and the relationships between second-order meanings and between the two tiers of significance. The result of the Clause's 2011 amendments was that this caseload came to signify multiple new meanings to the actors involved in these negotiations, and much of their existing significance was accentuated. This account sketches some of these meanings, but is clearly not exhaustive. To Rwandan authorities, these connotations were sufficiently concerning that they came to privilege any consensus around the Clause's future application over securing material durable solutions.

\footnotetext{
${ }^{26}$ Interview with rights-based NGO, Kampala. October 2013.

${ }^{27}$ Interview with Rwandan refugee, Kampala. November 2013.
} 
For UNHCR and the GoU - for whom the Rwandan caseload had also come to be synecdochical for numerous issues beyond its original signifiers and signified - this provided welcome space to manoeuvre. Having "abandoned a plan to move forward", ${ }^{28}$ these actors were content to produce 'Potemkin' plans for the Clause's implementation. This politicking established and relied upon a perceived disconnect between 'Rwandan refugees' as discussed in international forums and displaced individuals on the ground; between the refugee at the first-order of the sign and its symbolic counterpart at the second-order of signification (Cole 2015). For many Rwandan refugees in Uganda, the result has been a deterioration in their security situation as new systems of significance surrounding their status have complicated their right and access to protection.

The approach taken in this article draws attention to identifying whether negotiations to address a given situation focus predominantly on ameliorating what defines it at the level of signification, while practical actions remain consciously underdeveloped. As 'definitional fights' and unworkable rhetoric form key components of contemporary geopolitics, as epitomised in the recent EU-Turkey deal over Syrian refugees, theorising the link between the people on the ground and the 'objects' under discussion seems critical. Words can become detached from their original referent, leaving work to be done in piecing this relationship back together.

This affirms the importance of exploring the political geographies of words, and refocusing attention on these entities as much-needed and under-explored objects of critical geographical enquiry. This can be done through approaching words as signs, thus opening them to being conceptualised as contested and multi-faceted spaces of meaning with diverse and itinerant geographies of their own. As illustrated in this paper, this approach, pursued through socio-semiotic theories and methodologies, can be pursued in at least four main ways.

First, semiotic approaches encourage a reading of space that is sensitive to the simultaneity of meanings that co-exist across and throughout spatial and temporal scales (Hinchcliffe 2003). All signifieds can thus be situated and explored as partial readings of experiences and landscapes, illustrative of particular

\footnotetext{
${ }^{28}$ Interview with senior staff member at refugee rights organisation, Kampala. November 2013.
} 
political, academic or institutional interpretations (Foucault 1990). Geographical scholarship can, at times, for example, be seen to have de-emphasised the legal-normative component of the refugee label. Refugees are presented as 'occup[ing] a space external to the political community of the nation-state' (Daley 2013, 895; Stephens 2006), as individuals 'stripped of their legal and political standing, having been divested of anything but their biological nature' (Branch 2009, 496; Ek 2006; Minca 2006; Arendt 1943; Agamben 1998; Hyndman et al 2011). While these critical accounts convey the desperation of certain refugee situations, there are reasons for emphasising that fulfilling the refugee definition technically constitutes neither a loss of citizenship nor of rights. Refugee law is clearly inadequate in many situations for innumerable reasons. Ideas may be "twisted in translation" as they traverse contexts and space (Couper 2007, 291; Gregory 2006) or, to follow Agamben (1999, 171), refugee law may constitute another legal system in the contemporary sovereign order that 'is in force but without significance.' States may indeed simply play 'hide-and-seek' with the substance of legal commitments, as the Rwandan government did in attempting to associate the refugee label only with those displaced during war.

The term's original signified nonetheless constitutes a legal buttress, drawn from the 1951 Convention and accompanying frameworks, which enumerates the rights and responsibilities that refugees should be accorded. As this article illustrates, negative repercussions may arise if second-order signifieds occlude the label's legal-normative basis or original signifier, whether benevolently motivated or not. Without perpetuating 'semio-violence' (Hyndman et al 2011) by suggesting that accounts of refugees' experiences and characteristics are not essential, or denying that it is critical that organisations do not see all refugees as the same, this paper highlights the importance of identifying when refugees should be re-situated as individuals associated with binding legal frameworks.

Second, it draws analytical attention to the evolving conceptual and geographical relationship, perceived and in practice, between these different connotations. The mapping of these auxiliary signifieds does not obey neat spatial dichotomies, such as the emergence of rigid identities from 'above'/'macro-level statistics' and unstable representations 'from below'/the 'micro-level corollary' (McConnell 2013, Branch 2009), and it should not follow only one constituent part of a sign. Focusing 
on objects alone may, for example, mean that phenomena specifically related to the co-constitutive nature of the representational, the material and the experiential are lost. This paper thus adds to the scholarship challenging the distinction between 'immaterial cultural processes, [and] the constitution of intersubjective meaning systems' on the one hand, and the physical, 'bump-into-able' aspects of geography on the other (Philo 2000, 33). It does so not through theorising the ontological basis of this distinction, but through observing linguistic praxis. The actors above sought and failed to establish a geographical and practical distance between their 'intersubjective meaning systems' and the refugees themselves. This failure was in part because they collapsed any meaningful distinction between the two, by using the flexibility of linguistic space to simultaneously signify material, immaterial, intersubjective, legal and experiential meanings of 'Rwandan refugees'. The array of connotations that became associated with this caseload, through the refugees' behaviour and that of individuals interacting with them, then clearly impacted back upon the refugees' physical, psycho-social and legal security in unanticipated ways, again changing the ways that 'Rwandan refugees' were 'read'. Barthes' two-order framework highlights this interdependent and iterative relationship between the manifold components that simultaneously exist within the space of this label. Semiotics provides one heuristic for untangling these meanings.

Third, and relatedly, this perspective enables us to engage with the politics of establishing 'solutions' for refugees in ways sensitive to the heterogeneity of social worlds and interdependent spaces that provide the meanings and sub-texts for these discussions. Protracted refugee situations, such as Afghans in Pakistan or Eritreans in Sudan, undoubtedly accentuate the label's complexity. Over time, and across discussions occurring in interconnected and transnational spaces and mediums, the polysemic label 'refugee' becomes embellished - intentionally or not - with additional layers of meaning. Understanding how a consensus over the end of refugee status may be arrived at thus implicitly entails identifying what significance a caseload has come to possess and invoke to each actor engaged with it. It involves asking questions such as, do States' concerns about refugee flows stem from the bodies on the ground and/or the multiple significances attached to this label? And what is the intended and actual relationship between these various interpretations? 
Fourth, alongside geography's embrace of tracing objects around networks (Darling 2014), this paper argues for paying similar methodological attention to the circulation of linguistic conventions and words across spaces and discursive fields. Kearnes $(2003,144)$ states that the methodological distinction between 'textual' and 'material' approaches persists due to the lingering 'palpable distrust of contemporary semiotic, textual and deconstructive methodologies.' As a result, 'what remains substantially under theorized given the current discomfort with representation as a core concept within theories of mobility, is the nature, making, transmission and understanding of meanings themselves' (Revill 2011, 378). With the influence of 'meanings' repositioned as a critical component of studies of mobility, movement and geography, however, the ethnographic 'mobile methodologies' (Fincham et al 2010) and multi-sited ethnographies adopted to follow those on the move become just as applicable and, given the consequences of interpretation discussed above, just as important for also tracing their labels, identifying when, where and why particular connotations emerge, and exploring the potential repercussions of this iterative and contested landscape of meaning (Müller 2008, Revill 2011). This can also serve to position geographies of representation firmly within analyses of spaces of negotiation, thus situating these encounters as nodes in networks of significance with extensive and competing genealogies.

With the structuralist and historically narrow emphasis of traditional semiotic approaches hopefully transcended, this article shows how a socially-situated semiotic framework can help explain a particular incident of political wrangling. More broadly, however, it has utility for questioning and analysing the relationship between politics, policy and practice through the different spaces, including words, that they play out in. It does so not only through mapping the multiple perspectives held on any entity that has the potential of a sign to encompass and portray manifold meanings, as has been done with phenomena such as climate change (Arnall and Kothari 2015), but through seeking to render visible possible connections between material, representational and symbolic registers. Such a task could only be briefly sketched in this article. It nonetheless seeks to lay foundations - theoretically, methodologically and normatively - for greater disciplinary engagement with the political geography of words and their meanings. 


\section{Acknowledgements}

This research was supported by the Economic and Social Research Council. Many thanks to Maan Barua, Fiona McConnell, Luisa Enria and Tom Scott-Smith for their earlier comments on this paper, and to the seven anonymous reviewers who provided invaluable and patient feedback over two versions of this article. My greatest thanks go to all those who spoke to me during my time in Uganda, Rwanda and Geneva, particularly staff at OPM, MIDIMAR and the many Rwandan refugees who generously recounted their experiences and views to me. Any errors of interpretation are my fault alone.

\section{References}

Agamben G 1998 Homo Sacer: Sovereign Power and Bare Life Stanford University Press, Stanford

Agamben G 1999 Potentialities—Collected Essays in Philosophy Stanford University Press, Stanford

Arendt H 1943 We refugees Menorah Journal 31 69-77

Arnall A and Kothari U 2015 Challenging climate change and migration discourse: Different understandings of timescale and temporality in the Maldives Global Environmental Change 31 199-206

Barnes T and Duncan J S 2013 Writing world: discourse, text and metaphor in the representation of landscape Routledge

Barthes R 1972 Mythologies, The Complete Edition, in a New Translation Macmillan

Barua M 2013 Circulating elephants: unpacking the geographies of a cosmopolitan animal Transactions of the Institute of British Geographers 39 559-573

Baudrillard J 1981 Simulacra and Simulation

(http://fields.ace.ed.ac.uk/disruptivetechnologies/wp-content/uploads/2011/10/Baudrillard-JeanSimulacra-And-Simulation2.pdf)

Betts A and Loescher G 2010 eds Refugees in international relations Oxford University Press, Oxford

Black R 2002 Conceptions of 'home' and the political geography of refugee repatriation: between assumption and contested reality in Bosnia-Herzegovina Applied Geography 22 123138

Blommaert J 2010 The Sociolinguistics of Globalization Cambridge University Press, Cambridge

Boogaart T 2001 The Power of Place: From Semiotics to Ethnogeography Middle States Geographer 34 38-47 
Branch A 2009 Humanitarianism, Violence, and the Camp in Northern Uganda Civil Wars 11 477-501

Ceyhan A and Tsoukala A 2002 The Securitisation of Migration in Western Societies: Ambivalent Discourses and Politics Alternatives 27 21-39

Chandler D 2007 Semiotics: The Basics Routledge

Cole G 2015 Negotiating Durable Solutions for Refugees: A Critical Space for Semiotic Analysis International Journal for the Semiotics of Law 29 9-27

Couper P 2007 Fluvial geomorphology and semiotics: a Wittgensteinian perspective of the 'divide' between human and physical geography Transactions of the Institute of British Geographers 32 279-294

Curt B 1994 Textuality and Tectonics Open University Press, Milton Keynes

Darling J 2014 Another letter from the Home Office: reading the material politics of asylum Environment and Planning D: Society and Space 32 484-500

Daley P 2013 Refugees, idps and Citizenship Rights; the perils of humanitarianism in the Great Lakes Region Third World Quarterly 34 893-912

Diken B 2004 From refugee camps to gated communities: biopolitics and the end of the city Citizenship Studies 8 83-106

Duncan J and Duncan N 1988 ReReading the landscape Environment and Planning D: Society and Space 6 117-126

Eco U 1976 A theory of semiotics Indiana University Press, Indiana

Eco U 1984 The role of the reader: Explorations in the semiotics of texts. Indiana University Press

Ek R 2006 Giorgio Agamben and the spatialities of the camp: an introduction Geografiska Annaler: Series B, Human Geography 88 363-485

Fahamu 2011 Rwanda: Cessation of Refugee Status is Unwarranted. Memorandum of Fact and Law Fahamu, 22 September (http://www.srlan.org/sites/srlan/files/fileuploads/Memo\%20of\%20Fact\%20and\%20Law.pdf) Accessed 12 February 2012

Fahamu 2012 Rwanda the Cessation Clause Again: Question from Manzi, entitled, 'I am confused" Fahamu Refugee Legal Aid (http://www.frlan.org/content/calls-action)

Fincham B, McGuinness M and Murray L 2010 Mobile Methodologies Palgrave Macmillan, UK

Fitzpatrick J 1998 End of Protection: Legal Standards for Cessation of Refugee Status and Withdrawal of Temporary Protection Georgetown Immigration Law Journal 13 343-383

Flowerdew R and Martin D 2005 Methods in Human Geography: a guide for students doing a research project Harlow, UK 
Gibney M 2004 The Ethics and Politics of Asylum: Liberal Democracy and the Response to Refugees Cambridge University Press, Cambridge

Goodwin C 2000 Practises of Seeing: Visual Analysis: An Ethnomethodological Approach 157182 in Van Leeuwen T and Jewitt C eds Handbook of Visual Analysis Sage Publications, London

Gregory D 2006 The black flag: Guantanamo Bay and the space of exception Geografiska Annaler: Series B, Human Geography 88 405-427

Haddad E 2003 The Refugee: The Individual between Sovereigns Cambridge University Press, Cambridge

Hardy C and Phillips N 1999 No Joking Matter: Discursive Struggle in the Canadian Refugee System Organization Studies 20 1-24

Hilhorst D, Weijers L and van Wessel M 2012 Aid Relations and Aid Legitimacy: mutual imaging of aid workers and recipients in Nepal Third World Quarterly 33 1439-1457

Hinchcliffe S 2003 Inhabiting - Landscape and Natures 207-226 in Anderson K, Domosh M and Thrift $\mathbf{N}$ eds Handbook of Cultural Geography Sage Publications, London

Ho E 2013 'Refugee' or 'returnee'? The ethnic geopolitics of diasporic resettlement in China and intergenerational change Transactions of the Institute of British Geographers 38 599-611

Hoggart K, Lees L and Davies A 2001 Researching Human Geography Routledge, London Hovil L 2010 A Dangerous Impasse: Rwandan Refugees in Uganda Citizenship and Displacement in the Great lakes Region, Working Paper No. 4.

(http://allafrica.com/download/resource/main/main/idatcs/00020187:8e216155a19bfd8b58039d1 bc7e03045.pdf)

Howland T 1998 Refoulement of Rwandan Refugees: the UNHCR's Lost Opportunity to Ground Temporary Refuge in Human Rights Law U.C. Davis J. Int'l L. and Pol'y 4 73-102 Human Rights Watch 2010 Uganda/Rwanda: Half Forced Returns of Refugees 17 July (http://www.hrw.org/news/2010/07/16/ugandarwanda-halt-forced-returns-refugees)

Huysman J 2000 The European Union and the Securitisation of Migration Journal of Common Market Studies 38751-77

Hyndman J and Giles W 2011 Waiting for what? The feminization of asylum in protracted situations Gender, Place \& Culture: A journal of Feminist Geography 18 361-379

IRIN 2012 Rwandan refugees still reluctant to repatriate, 14th March (http://www.irinnews.org/report/95072/uganda-rwandan-refugees-still-reluctant-repatriate) Irvine J T 1989 When Talk Isn't Cheap: Language and Political Economy American Ethnologist $16248-267$

Isin E 2009 Citizenship in flux: The figure of the activist citizen Subjectivity 29 367-388 
Jackson P 2000 Rematerialising social and cultural geography Social \& Cultural Geography 1 9-14

Jensen K 1995 The Social Semiotics of Mass Communication Sage, London

Kabeera E 2011 Gatsinzi urges refugees in Mozambique to return The New Times, 20

September (http://www.newtimes.co.rw/news/index.php?a=45380\&i=14754)

Kagame P 2011 Monthly Press Conference, 11th October (http://www.gov.rw/PresidentKagame-holds-monthly-press-conference-Urugwiro-Village-11-October-2011)

Kagire E 2012 Rwanda: UNHCR Invokes Cessation Clause All Africa 5 January (http://allafrica.com/stories/201201050390.html)

Kagire E 2013 No more refugee status for Rwandans abroad The East African, 6 July (http://www.theeastafrican.co.ke/news/Rwandan-exiles-lose-refugee-status-after-19-years//2558/1906954/-/4od7nz/-/index.html)

Kearnes M 2003 Geographies that matter - the rhetorical deployment of physicality? Social and Cultural Geography 4 139-152

Kirby V 1999 Human Nature Australian Feminist Studies 14 19-29

Khalili L 2005 Places of memory and mourning: Palestinian commemoration in the refugee camps of Lebanon Comparative Studies of South Asia, Africa and the Middle East 25 30-45

Kouyate M 2010 Uganda: Over 1,000,000 Rwanda refugees face forced repatriation from Uganda Rwandarwabanyarwanda,19 May (http://rwandarwabanyarwanda.over-blog.com/articleuganda-over-1-000-000-rwandan-refugees-face-forced-repatriation-from-uganda50734670.html)

Kumsa M K 2006 No! I'm Not a Refugee! The Poetics of Be-Longing among Young Oromos in Toronto Journal of Refugee Studies 19 230-255

Lagopoulos A 1993 Postmodernism, geography, and the social semiotics of space Environment and Planning D 11 255-255.

Lindström K, Palang H and Kull K 2012 Semiotics of Landscape p97-107 in Howard P, Thompson I and Waterton E (eds) The Routledge Companion to Landscape Studies Routledge, Oxford

Lischer S 2006 Dangerous Sanctuaries: refugee camps, civil war, and the dilemmas of humanitarian aid Cornell University Press, Ithaca

Loescher G 1992 Refugee Movements and International Security Adelphi Paper 268, International Institute for Strategic Studies, Brassey's, London

McMillan K 2012 Uganda's Invocation of the Cessation Regarding its Rwandan Refugee Caseload: Lessons for International Protection International Journal of Refugee Law

Malkki L 1992 National Geographic: The rooting of peoples and the Territorialisation of National Identity among Scholars and Refugees Cultural Anthropology 7 24-44 
Malkki L 1996 Speechless Emissaries: Refugees, Humanitarianism, and Dehistoricisation Cultural Anthropology 11 377-404

McConnell F 2013 Citizens and Refugees: Constructing and Negotiating Tibetan Identities in Exile Annals of the Association of American Geographers 103 967-983

McDonough D S 2008 From Guerrillas to Government: post-conflict stability in Liberia, Uganda and Rwanda Third World Quarterly 29 357-374.

Metro-Roland M 2011 Tourists, signs and the city: the semiotics of culture in an urban landscape Surrey, Ashgate

Mills K and Norton R 2002 Refugees and security in the Great Lakes Region of Africa Civil Wars 5 1-26

Minca C 2006 Giorgio Agamben and the new biopolitical nomos Geografiska Annaler: Series B, Human Geography 88 387-403

Miwambo N 2014 Muhoozi accused of killing, kidnapping \& extraditing Rwandans The London Evening Post, 1 April (http://www.thelondoneveningpost.com/muhoozi-accused-of-killingkidnapping-extraditing-rwandans/)

Mol A 2003 The Body Multiple: Ontology in Medical Practice Durham, Duke University Press Müller M 2007 Reconsidering the concept of discourse for the field of critical geopolitics: Towards discourse as language and practice Political Geography 27 322-338

Nyamwasa K, Karegeya P, Rudasingwa T and Gahima G 2010 Rwanda Briefing (http://afjn.org/act-now/resources.html)

Owens P 2009 Reclaiming 'bare life'?: Against Agamben on refugees International Relations 23 567-582

Painter J 2006 Prosaic geographers of stateness Political Geography 25 752-774

Peteet J 2005a Landscape of hope and despair: Palestinian refugee camps Pennsylvia, University of Pennsylvania Press

Peteet J 2005b Words as interventions: naming in the Palestine-Israel conflict Third World Quarterly 26 153-172

Philo C 2000 More words, more worlds: reflections on the 'cultural turn' and human geography p26-53 in Cook I, Crouch D, Naylor S and Ryan J R eds. Cultural Turns/Geographical Turns: Perspectives on Cultural Geography Prentice Hall

Ramadan A 2012 Spatialising the refugee camp Transactions of the Institute of British Geographers 38 65-77

Revill G 2011 Mobility - Part II 373-387 in Agnew J and Duncan J (eds) The Wiley-Blackwell companion to human geography Wiley-Blackwell, Chichester

Rogin M 1990 "Make My Day!": Spectacle as Amnesia in Imperial Politics Representations 29 99-123 
Rose G 1993 Feminism and Geography: The Limits of Geographical Knowledge Polity, Cambridge

Sanyal R 2014 Hindu Space: Urban Dislocations in post-partition Calcutta Transactions of the Institute of British Geographers 39 38-49

Saussure F 1983 Course in General Linguistics, trans Rolf Harris, Duckworth, London

Scollon R and Scollon S 2003 Discourses in Place: Language in the Material World Routledge, London

Shacknove A 1985 Who Is A Refugee? Ethics 95 274-284

Shortell T 2016 Everyday Globalisation: A Spatial Semiotics of Immigrant Neighbourhoods in Brooklyn and Paris Routledge, London

Stephens J 2006 Prisons of the Stateless: the derelictions of UNHCR New Left Review 42 53-67 Tarwater J 2000 Analysis and Case Studies of the Ceased Circumstances Cessation Clause of the 1951 Refugee Convention Georgetown Immigration Law Journal 15 563-624

UK Immigrant Magazine 2011 Rwandan refugees reluctant to repatriate, 3 November (http://immigrantmagazine.co.uk/?p=6775)

UN General Assembly 1951 Convention Relating to the Status of Refugees (www.refworld.org/docid/3be01b964.html) Accessed 3 September 2014

UNHCR 2009 UNHCR and Rwanda seek enduring solutions for refugee situation, 20 October (www.unhcr.org/4addd7fd9.html)

UNHCR 2010a Statistical Yearbook (http://www.unhcr.org/4ef9c7269.html)

UNHCR 2010b Submission by the United Nations High Commissioner for Refugees for the Office of the High Commissioner for Human Rights' Compilation Report - Universal Periodic Review: Rwanda (http://www.unhcr.org/refworld/docid/4c3abf172.html) Accessed 8 April 2012

UNHCR 2010c UNHCR condemns forced return of 1,700 Rwandans from Uganda News Stories, 16 July (http://www.unhcr.org/4c406edb6.html)

UNHCR 2011 Implementation of the Comprehensive Strategy for the Rwandan Refugee Situation, including UNHCR's recommendations on the Applicability of the 'Ceased Circumstances' Cessation Clauses, 31 December (http://www.unhcr.org/refworld/docid/4f33a1642.html)

Van Leeuwen T 2005 Introducing Social Semiotics Routledge, London

Vannini P 2007 Social Semiotics and Fieldwork: Methods and Analytics Qualitative Inquiry 13 113-140

Vasudevan A 2003 Writing the asphalt jungle: Berlin and the performance of classical modernity 1900-33 Environment and planning D 21 169-194

Von Uexküll T 1982 Introduction: Meaning and Science in Jakob von Uexküll's concept of biology Semiotica 42 1-24 
Zetter R 1991 Labelling Refugees: Forming and Transforming a Bureaucratic Identity Journal of Refugee Studies 4 39-62

Zetter R 2007 More labels, fewer refugees: remaking the refugee label in an era of globalisation Journal of Refugee Studies 20 172-192 